\title{
Chemical potato protection in Poland and the neighboring countries
}

\section{Chemiczna ochrona ziemniaka w Polsce i krajach sąsiednich}

\author{
Joanna Sobczak ${ }^{1}$, Grzegorz Lemańczyk², Ewa Matyjaszczyk ${ }^{1 *}$
}

\begin{abstract}
Summary
Data regarding the availability of products for potato protection in January 2017 in Poland and the neighboring countries: Czech Republic, Lithuania, Germany, Slovakia are presented and analyzed in this paper. Significant differences among countries have been observed. The highest number of products for potato protection is registered in Czech Republic while the lowest in Lithuania. The number of registered products does not always reflect their diversity. The number of chemical groups of active substances varies depending on the group of product and it is the highest for herbicides and insecticides in Germany while for fungicides in Czech Republic. Regardless of product group, availability of active substances, as well as their groups it is the lowest in Lithuania. Because of tight availability of insecticides in Lithuania there is a concern about the possibility of proper resistance management. Products containing mixture of two active substances constitute about $40 \%$ of registered formulations of fungicides, below $20 \%$ of insecticides and below $10 \%$ of herbicides. Different mixtures are often registered in individual countries. Availability of biological products for potato protection is still low. There are comparatively few products that are registered and they are not available in all countries.
\end{abstract}

Key words: active substances; availability; chemical groups; fungicides; herbicides; insecticides; plant protection; potato; registration; resistance

\section{Streszczenie}

W artykule zaprezentowano i przeanalizowano dane dotyczące dostępności środków do ochrony ziemniaka w styczniu 2017 w Polsce i krajach sąsiednich: Czechach, Litwie, Niemczech i Słowacji. Zaobserwowano znaczne różnice pomiędzy krajami. Najwięcej środków do ochrony ziemniaka zarejestrowano w Czechach, a najmniej na Litwie. Liczba zarejestrowanych środków nie zawsze odzwierciedla ich różnorodność. Liczba grup chemicznych substancji czynnych zależy od grupy produktów i dla herbicydów oraz insektycydów jest najwyższa w Niemczech, podczas gdy dla fungicydów w Czechach. Niezależnie od grupy środków dostępność zarówno substancji czynnych, jak i ich grup chemicznych jest najniższa na Litwie. Ze względu na niewielką dostępność insektycydów na Litwie zachodzi obawa odnośnie możliwości właściwego prowadzenia strategii antyodpornościowej. Środki zawierające mieszaninę dwóch substancji czynnych stanowią około $40 \%$ zarejestrowanych formulacji fungicydów, poniżej $20 \%$ insektycydów i poniżej 10\% herbicydów. W poszczególnych krajach są często zarejestrowane odmienne mieszaniny. Dostępność środków biologicznych do ochrony ziemniaka jest nadal niska. Zarejestrowanych jest relatywnie niewiele produktów i nie są one dostępne we wszystkich krajach.

Słowa kluczowe: substancje czynne; dostępność; grupy chemiczne; fungicydy; herbicydy; insektycydy; ochrona roślin; ziemniak; rejestracja; odporność

\footnotetext{
${ }^{1}$ Instytut Ochrony Roślin - Państwowy Instytut Badawczy

Zakład Ekspertyz i Opinii o Środkach Ochrony Roślin

Władysława Węgorka 20, 60-318 Poznań

2 Uniwersytet Technologiczno-Przyrodniczy im. Jana i Jędrzeja Śniadeckich w Bydgoszczy

Zakład Fitopatologii Molekularnej

Kordeckiego 20, 85-225 Bydgoszcz

*corresponding author: e.matyjaszczyk@iorpib.poznan.pl
} 


\section{Wstęp / Introduction}

Uprawa ziemniaka ma duże znaczenie w Polsce i krajach sąsiednich. Polska posiada największy areał ziemniaka wśród państw Unii Europejskiej - 320 tys. ha. Niemcy zajmują drugie miejsce $\mathrm{z}$ areałem 235,5 tys. ha. Ziemniak jest powszechnie uprawiany także $w$ innych krajach sąsiadujących z Polską. Zgodnie z danymi Eurostatu (2017) powierzchnia uprawy ziemniaka wynosiła: 23,41 tys. ha w Czechach, 21,2 tys. ha na Litwie i 8,27 tys. ha na Słowacji.

Jednym $\mathrm{z}$ założeń integrowanej ochrony roślin jest przeciwdziałanie powstawaniu odporności organizmów szkodliwych na środki ochrony roślin poprzez właściwy dobór i przemienne stosowanie tych środków (Mrówczyński 2013). W przypadku ochrony ziemniaka, a szczególnie jego ochrony przed chorobami należy położyć nacisk na strategię antyodpornościową, ponieważ w zależności od nasilenia występowania organizmów szkodliwych, wykonuje się nierzadko kilkanaście zabiegów w sezonie. Dostępność preparatów, zawierających substancje czynne z różnych grup chemicznych o odmiennych mechanizmach działania jest ważna z punktu widzenia zapobiegania uodparnianiu się agrofagów na środki chemiczne i pozwala na rotację preparatów (Nowaczyk i Obrępalska-Stęplowska 2006; Adamczewski i wsp. 2014; Matyjaszczyk i wsp. 2015; Matyjaszczyk i Sobczak 2017a). Liczne dane literaturowe wskazują na to, że zarówno organizm grzybopodobny Phytophthora infestans sprawca zarazy ziemniaka, jak i grzyby z rodzaju Alternaria, sprawcy alternariozy oraz stonka ziemniaczana występują powszechnie oraz często uodparniają się na środki chemiczne (Kapsa 2002; Węgorek 2007; EPPO 2015; Lemańczyk i Lisiecki 2015).

Celem niniejszej analizy jest porównanie dostępności środków do ochrony ziemniaka w Polsce i krajach sąsiednich należących do Unii Europejskiej (Niemcy, Czechy, Słowacja, Litwa).

\section{Materiały i metody / Materials and methods}

Analizę środków ochrony roślin wykonano według stanu na styczeń 2017 roku w Polsce, Niemczech, Czechach, Słowacji i na Litwie. Przeanalizowano dostępność preparatów należących do trzech głównych grup: herbicydów, fungicydów i insektycydów. Desykanty włączono do grupy herbicydów, natomiast środków należących do innych grup (w tym moluskocydów, regulatorów wzrostu i nematocydów) nie uwzględniono.

Źródłem danych były oficjalne rejestry środków ochrony roślin, dostępne na stronach internetowych instytucji odpowiedzialnych za rejestrację w poszczególnych państwach członkowskich (BVL 2017; MRiRW 2017; The State Plant Service 2017; ÚKSÚP 2017; ÚKZÚZ 2017). Rejestry przeanalizowano pod kątem dostępności zarówno samych środków ochrony roślin, jak i substancji czynnych oraz częściowo składu (tzn. czy substancje czynne występują samodzielnie czy w mieszaninach). Substancje czynne poddano dalszej analizie pod kątem przynależności do grup chemicznych oraz mechanizmów działania. Kwalifikacji do poszczególnych grup chemicznych i mechanizmów działania dokonano na podstawie międzynarodowych baz danych (HRAC, FRAC, IRAC) oraz kompendium (The Pesticide Manual 2012).

\section{Wyniki i dyskusja / Results and discussion}

Wyniki analizy dostępności środków ochrony roślin w poszczególnych krajach zestawiono w tabelach 1-3. Ogółem najwięcej preparatów do ochrony ziemniaka dostępnych jest w Czechach (387), gdzie areał uprawy jest ponad 10-krotnie mniejszy w porównaniu z Polską czy Niemcami. Z kolei najmniej środków dostępnych jest na Litwie (63). W Polsce zarejestrowanych mamy 278 środków, w Niemczech 251, a na Słowacji 173.

Przyglądając się poszczególnym grupom agrochemikaliów można zauważyć, że najwięcej fungicydów zarejestrowanych jest w Polsce. Czeski rynek z kolei najlepiej zaopatrzony jest w herbicydy i insektycydy, mimo tego, że w kraju tym uprawia się znacznie mniej ziemniaka w porównaniu z Polską czy Niemcami. Znaczną część fungicydów, we wszystkich krajach stanowią formulacje zawierające dwie substancje czynne, różniące się mechanizmem działania (tab. 1). Są one cennym uzupełnieniem programów ochrony ziemniaka z punktu widzenia zapobiegania odporności agrofagów na środki ochrony roślin. Największy udział takich formulacji (mieszanin) odnotowano na Słowacji i w Polsce, gdzie stanowią odpowiednio 47\% i 45\% ogółu dostępnych fungicydów. W pozostałych krajach ich udział jest następujący: 43\% (Litwa), 40\% (Czechy) i 37\% (Niemcy). W analizowanych państwach członkowskich formulacje zawierające mieszaninę dwóch substancji czynnych stanowią do $10 \%$ ogółu herbicydów oraz od $8 \%$ do $20 \%$ ogółu dostępnych insektycydów.

Dostępność agrochemikaliów przeanalizowano także pod kątem substancji czynnych oraz grup chemicznych. Analizując fungicydy można zauważyć zróżnicowanie w tym zakresie. Najmniej substancji oraz grup chemicznych odnotowano na Litwie, a najwięcej w Czechach (tab. 1). W Czechach było najwięcej fungicydów o różnych mechanizmach działania (19), a na Litwie najmniej (16). Warto zaznaczyć, że substancje czynne z różnych grup chemicznych mogą mieć taki sam mechanizm działania. Przykładowo w Niemczech 25 substancji z różnych grup reprezentowało 17 różnych mechanizmów działania. Podczas analizy stwierdzono również, że nie we wszystkich krajach dostępne są takie same substancje czynne. W ochronie przed patogenami we wszystkich analizowanych państwach stosowane 
Tabela 1. Fungicydy do ochrony ziemniaka w Polsce i krajach sąsiadujących (zgodnie z danymi ze stycznia 2017)

Table 1. Fungicides for the protection of potato in Poland and the neighboring countries (according to the data from January 2017)

\begin{tabular}{|c|c|c|c|c|c|}
\hline \multirow{2}{*}{$\begin{array}{l}\text { Substancje czynne } \\
\text { Active substances }\end{array}$} & \multicolumn{5}{|c|}{ Liczba środków - Number of products } \\
\hline & $\begin{array}{l}\text { Polska } \\
\text { Poland }\end{array}$ & $\begin{array}{l}\text { Niemcy } \\
\text { Germany }\end{array}$ & $\begin{array}{c}\text { Czechy } \\
\text { Czech Republic }\end{array}$ & $\begin{array}{l}\text { Litwa } \\
\text { Lithuania }\end{array}$ & $\begin{array}{l}\text { Słowacja } \\
\text { Slovakia }\end{array}$ \\
\hline 1 & 2 & 3 & 4 & 5 & 6 \\
\hline Amisulbrom & - & 1 & - & 1 & - \\
\hline Azoxystrobin & 22 & 15 & 15 & 1 & 1 \\
\hline Chlorothalonil & 6 & - & 1 & - & 3 \\
\hline Coniothyrium minitans & - & 1 & - & - & - \\
\hline Copper & 7 & 6 & 12 & 1 & 2 \\
\hline Cyazofamid & 2 & 1 & 2 & 1 & 1 \\
\hline Cymoxanil & 3 & - & 3 & - & 1 \\
\hline Difenoconazole & - & - & 1 & - & - \\
\hline Fluazinam & 11 & 9 & 10 & 5 & 4 \\
\hline Fludioxonil & - & - & - & - & 1 \\
\hline Flutolanil & 2 & 1 & 1 & - & - \\
\hline Folpet & 1 & - & - & - & 1 \\
\hline Imazalil & 1 & 1 & - & - & - \\
\hline Iprodione & - & - & - & 1 & - \\
\hline Mancozeb & 9 & 8 & 10 & 5 & 7 \\
\hline Mandipropamid & 1 & 1 & 3 & 1 & 1 \\
\hline Maneb & - & 2 & - & - & - \\
\hline Metiram & 1 & 3 & 1 & - & 1 \\
\hline Pencycuron & 2 & - & 1 & - & 1 \\
\hline Penflufen & 1 & - & 1 & - & - \\
\hline Propineb & 1 & - & 1 & - & 1 \\
\hline Pseudomonas sp. Kmen DSZM13134 & - & - & 1 & - & - \\
\hline Pythium oligandrum & - & - & 2 & - & 1 \\
\hline Tolclofos-methyl & - & - & 1 & - & - \\
\hline Ametoctradin + dimethomorph & 1 & 1 & - & 1 & - \\
\hline Ametoctradin + mancozeb & 1 & - & 1 & - & - \\
\hline Amisulbrom + mancozeb & - & 1 & - & - & - \\
\hline Azoxystrobin + fluazinam & - & - & 1 & - & - \\
\hline Benalaxyl + mancozeb & 1 & - & 2 & - & 1 \\
\hline Benalaxyl-M + mancozeb & 1 & 1 & 1 & - & 1 \\
\hline Benthiavalicarb + mancozeb & 1 & 1 & 1 & - & - \\
\hline Boscalid + pyraclostrobin & - & 1 & - & 1 & 1 \\
\hline Carboxin + thiram & - & - & 1 & - & - \\
\hline Chlorothalonil + cymoxanil & 1 & - & 1 & - & 1 \\
\hline Chlorothalonil + propamocarb & - & 1 & - & - & - \\
\hline Cymoxanil + copper & 2 & - & - & - & - \\
\hline Cymoxanil + famoxadone & 3 & 1 & 2 & - & 1 \\
\hline Cymoxanil + fluazinam & 3 & - & 2 & - & - \\
\hline Cymoxanil + mancozeb & 14 & 4 & 10 & 1 & 7 \\
\hline Cymoxanil + mandipropamid & - & 1 & 2 & - & 1 \\
\hline Cymoxanil + propamocarb & 2 & 2 & 1 & - & - \\
\hline Cymoxanil + zoxamide & 2 & 1 & - & - & - \\
\hline
\end{tabular}




\begin{tabular}{|c|c|c|c|c|c|}
\hline 1 & 2 & 3 & 4 & 5 & 6 \\
\hline Difenoconazole + mandipropamid & 2 & 1 & 1 & 1 & 1 \\
\hline Dimethomorph + fluazinam & 1 & 1 & 1 & 1 & 1 \\
\hline Dimethomorph + mancozeb & 5 & 2 & 5 & 1 & 2 \\
\hline Dimethomorph + pyraclostrobin & 1 & - & - & - & - \\
\hline Dimethomorph + zoxamide & 1 & - & 1 & - & - \\
\hline Famoxadone + mancozeb & 1 & - & - & - & - \\
\hline Fenamidone + mancozeb & - & - & 1 & - & 1 \\
\hline Fenamidone + propamocarb & 1 & - & 1 & 1 & 1 \\
\hline Fenpropidin + propiconazole & - & - & - & 1 & - \\
\hline Fluazinam + metalaxyl-M & - & 1 & - & - & - \\
\hline Fluopicolid + propamocarb & 1 & 2 & 1 & 1 & 1 \\
\hline Mancozeb + mandipropamid & - & 1 & 1 & - & - \\
\hline Mancozeb + metalaxyl & 6 & - & - & - & - \\
\hline Mancozeb + metalaxyl-M & 3 & 1 & 1 & 1 & 1 \\
\hline Mancozeb + propamocarb & - & 1 & - & - & - \\
\hline Mancozeb + valifenalate & 2 & 1 & 2 & - & - \\
\hline Mancozeb + zoxamide & - & 1 & - & 1 & - \\
\hline Pencycuron + imidacloprid* & 1 & 1 & 2 & 1 & 1 \\
\hline Pencycuron + prothioconazole & 1 & 1 & 1 & - & 1 \\
\hline Penflufen + prothioconazole & - & - & 1 & - & - \\
\hline \multicolumn{6}{|c|}{ Łącznie - Total } \\
\hline $\begin{array}{l}\text { Liczba środków } \\
\text { Number of products }\end{array}$ & 128 & 78 & 110 & 28 & 49 \\
\hline $\begin{array}{l}\text { Liczba substancji czynnych } \\
\text { Number of active substances }\end{array}$ & 31 & 29 & 32 & 21 & 26 \\
\hline $\begin{array}{l}\text { Liczba grup chemicznych } \\
\text { Number of chemical groups }\end{array}$ & 24 & 25 & 24 & 20 & 21 \\
\hline
\end{tabular}

*pencykuron może być stosowany w mieszaninie z insektycydem - imidachloprydem - pencycuron can be used in mixture with the insecticide - imidacloprid

Źródło: opracowanie własne na podstawie rejestrów środków ochrony roślin z poszczególnych krajów oraz The Pesticide Manual

Source: own elaboration of plant protection products registers from individual countries and The Pesticide Manual

Tabela 2. Herbicydy do ochrony ziemniaka w Polsce i krajach sąsiadujących (zgodnie z danymi ze stycznia 2017)

Table 2. Herbicides for the protection of potato in Poland and the neighboring countries (according to the data from January 2017)

\begin{tabular}{l|c|c|c|c|c}
\hline \multirow{2}{*}{$\begin{array}{c}\text { Substancje czynne } \\
\text { Active substances }\end{array}$} & \multicolumn{5}{c}{ Liczba środków - Number of products } \\
\cline { 2 - 6 } & $\begin{array}{c}\text { Polska } \\
\text { Poland }\end{array}$ & $\begin{array}{c}\text { Niemcy } \\
\text { Germany }\end{array}$ & $\begin{array}{c}\text { Czechy } \\
\text { Czech Republic }\end{array}$ & $\begin{array}{c}\text { Litwa } \\
\text { Lithuania }\end{array}$ & $\begin{array}{c}\text { Słowacja } \\
\text { Slovakia }\end{array}$ \\
\hline Aclonifen & 2 & 3 & 4 & 5 & 6 \\
\hline Bentazon & - & 1 & 1 & 1 & 1 \\
\hline Carfentrazone-ethyl & 7 & - & 12 & - & 3 \\
\hline Clethodim & 1 & 1 & - & - & 1 \\
\hline Clomazone & 2 & 1 & - & 1 & 1 \\
\hline Cykloxydim & 7 & 3 & 31 & 1 & 4 \\
\hline Diquat & 12 & 1 & 2 & 2 & 2 \\
\hline Fluazifop-P-butyl & 2 & 2 & 5 & - & 11 \\
\hline Flurochloridone & 1 & - & 3 & - & 2 \\
\hline
\end{tabular}




\begin{tabular}{|c|c|c|c|c|c|}
\hline 1 & 2 & 3 & 4 & 5 & 6 \\
\hline Glufosinate-ammonium & 1 & - & 2 & - & - \\
\hline Glyphosate & 14 & 76 & 25 & 1 & 19 \\
\hline Linuron & 10 & - & 16 & 1 & 7 \\
\hline MCPA & - & - & - & 1 & - \\
\hline Metobromuron & 1 & 3 & 3 & - & - \\
\hline Metosulam & - & 1 & - & - & - \\
\hline Metribuzin & 7 & 4 & 16 & - & 5 \\
\hline Pelargonic acid & 1 & - & - & - & - \\
\hline Pendimethalin & 2 & - & - & 2 & 4 \\
\hline Propaquizafop & 2 & 1 & 12 & 1 & 10 \\
\hline Prosulfocarb & 1 & 2 & 2 & 2 & - \\
\hline Pyraflufen & - & 1 & 1 & - & - \\
\hline Quizalofop-p-ethyl & 7 & 5 & 9 & 3 & 6 \\
\hline Quizalofop-p-tefuryl & - & 1 & 3 & - & 2 \\
\hline Rimsulfuron & 10 & 3 & 11 & 1 & 4 \\
\hline S-metolachlor & - & - & 5 & - & 1 \\
\hline Aclonifen + clomazone & - & 1 & - & - & - \\
\hline Clomazone + linuron & 1 & - & 1 & 1 & - \\
\hline Clomazone + metazachlor & - & - & - & - & 1 \\
\hline Clomazone + metribuzin & 1 & 1 & 1 & 1 & - \\
\hline Clomazone + pendimethalin & 1 & - & 1 & - & - \\
\hline Flufenacet + metribuzin & 1 & 1 & 1 & - & 1 \\
\hline Metribuzin + prosulfocarb & 1 & 1 & 1 & - & 1 \\
\hline \multicolumn{6}{|c|}{ Łącznie - Total } \\
\hline $\begin{array}{l}\text { Liczba środków } \\
\text { Number of products }\end{array}$ & 94 & 119 & 187 & 20 & 87 \\
\hline $\begin{array}{l}\text { Liczba substancji czynnych } \\
\text { Number of active substances }\end{array}$ & 20 & 18 & 21 & 14 & 21 \\
\hline $\begin{array}{l}\text { Liczba grup chemicznych } \\
\text { Number of chemical groups }\end{array}$ & 16 & 14 & 17 & 12 & 16 \\
\hline
\end{tabular}

Źródło: opracowanie własne na podstawie rejestrów środków ochrony roślin z poszczególnych krajów oraz The Pesticide Manual

Source: own elaboration of plant protection products registers from individual countries and The Pesticide Manual

Tabela 3. Insektycydy do ochrony ziemniaka w Polsce i krajach sąsiadujących (zgodnie z danymi ze stycznia 2017)

Table 3. Insecticides for the protection of potato in Poland and the neighboring countries (according to the data from January 2017)

\begin{tabular}{l|c|c|c|c|c}
\hline \multirow{2}{*}{$\begin{array}{c}\text { Substancje czynne } \\
\text { Active substances }\end{array}$} & \multicolumn{5}{c}{ Liczba środków - Number of products } \\
\cline { 2 - 6 } & $\begin{array}{c}\text { Polska } \\
\text { Poland }\end{array}$ & $\begin{array}{c}\text { Niemcy } \\
\text { Germany }\end{array}$ & $\begin{array}{c}\text { Czechy } \\
\text { Czech Republic }\end{array}$ & $\begin{array}{c}\text { Litwa } \\
\text { Lithuania }\end{array}$ & $\begin{array}{c}\text { Słowacja } \\
\text { Slovakia }\end{array}$ \\
\hline Acetamiprid & 2 & 3 & 4 & 5 & 6 \\
\hline Alpha-cypermethrin & 8 & 4 & 8 & 1 & 4 \\
\hline Azadirachtin & - & 1 & 4 & 1 & 5 \\
\hline Bacillus thuringiensis subsp. tenebrionis & - & 6 & 1 & 1 & 1 \\
\hline Beta-cyfluthrin & 1 & 1 & - & - & - \\
\hline Chlorantraniliprole & 4 & 1 & 2 & 2 & 2 \\
\hline Chlothianidin & 1 & 1 & 1 & - & 1 \\
\hline Cypermethrin & 5 & 1 & - & - & 1 \\
\hline Deltamethrin & 6 & 6 & - & & 1 \\
\hline
\end{tabular}




\begin{tabular}{|c|c|c|c|c|c|}
\hline 1 & 2 & 3 & 4 & 5 & 6 \\
\hline Esfenvalerate & - & 2 & - & - & - \\
\hline Flonicamid & 1 & 1 & - & - & - \\
\hline Fosmet & 1 & - & - & - & - \\
\hline Gamma-cyhalothrin & 1 & - & 2 & - & - \\
\hline Imidacloprid & 1 & - & 1 & - & 1 \\
\hline Lambda-cyhalothrin & 10 & 11 & 15 & 2 & 3 \\
\hline Paraffin oil & - & - & - & 1 & - \\
\hline Pirimicarb & - & 2 & 9 & - & 1 \\
\hline Pymetrozine & - & 1 & 1 & - & - \\
\hline Spinosad & 1 & 2 & 1 & - & 1 \\
\hline Tau-fluvalinate & - & - & 1 & 1 & 1 \\
\hline Thiamethoxam & 1 & 1 & 2 & 1 & 2 \\
\hline Tiacloprid & 1 & 1 & 12 & - & 4 \\
\hline Zeta-cypermethrin & 5 & - & 8 & 1 & 3 \\
\hline Chlorpyrifos + cypermethrin & 5 & - & 10 & - & 1 \\
\hline Chlorpyrifos-methyl + cypermethrin & 1 & - & - & - & - \\
\hline Deltamethrin + tiacloprid & 1 & - & 3 & 1 & 1 \\
\hline Imidacloprid + pencycuron* & 1 & 1 & 2 & 1 & 1 \\
\hline Pyrethrins + rapeseed oil & - & 10 & - & - & - \\
\hline \multicolumn{6}{|c|}{ Łącznie - Total } \\
\hline $\begin{array}{l}\text { Liczba środków } \\
\text { Number of products }\end{array}$ & 56 & 54 & 90 & 15 & 37 \\
\hline $\begin{array}{l}\text { Liczba substancji czynnych } \\
\text { Number of active substances }\end{array}$ & 18 & 20 & 18 & 13 & 17 \\
\hline $\begin{array}{l}\text { Liczba grup chemicznych } \\
\text { Number of chemical groups }\end{array}$ & 7 & 11 & 8 & 4 & 7 \\
\hline
\end{tabular}

*imidachlopryd może być stosowany w mieszaninie z fungicydem - pencykuronem - imidacloprid can be used in mixture with the fungicide - pencycuron Źródło: opracowanie własne na podstawie rejestrów środków ochrony roślin z poszczególnych krajów

Source: own elaboration of plant protection products registers from individual countries

są: azoksystrobina, cyjazofamid, cymoksanil, difenokonazol, dimetomorf, famoksat, fluazynam, fluopikolid, mandipropamid, mankozeb, metalaksyl-M, miedź, pencykuron oraz propamokarb. Pozostałe substancje stosuje się jedynie w wybranych krajach, a część z nich tylko w jednym państwie, a są to: iprodion (LT), maneb (DE), grzyb Coniothyrium minitans (DE), metalaksyl (PL), fludioksonil (SK), karboksyna (CZ), tiuram (CZ), tolchlofos metylowy (CZ), bakteria Pseudomonas sp. (CZ), propikonazol (LT) i fenpropidyna (LT). W ochronie ziemniaka zastosowanie znajduje także wiele fungicydów zawierających dwie substancje czynne, a najczęściej występujące połączenia, które dostępne są we wszystkich rozpatrywanych krajach, to: cymoksanil + mankozeb, difenokonazol + mandipropamid, dimetomorf + fluazinam, dimetomorf + mankozeb, fluopikolid + propamokarb oraz mankozeb + metalaksyl-M.

W grupie herbicydów także widoczne jest zróżnicowanie dostępności substancji czynnych (tab. 2). Największą liczbą substancji chwastobójczych dysponują Czechy i Słowacja, a najmniej substancji oraz grup chemicznych jest na Litwie.
Najwięcej mechanizmów działania herbicydów odnotowano w Polsce i w Czechach (15), a najmniej na Litwie (11). Najbardziej powszechne substancje stosowane zarówno w Polsce, jak i krajach sąsiednich to: chizalofop-P etylu, chlomazon, cykloksydym, dikwat, glifosat, metrybuzyna, propachizafop, prosulfokarb i rimsulfuron. Pozostałe substancje zarejestrowane są do ochrony ziemniaka w wybranych państwach. Rzadko, bo tylko w jednym kraju stosuje się: MCPA (LT), metazachlor (SK), metosulam (DE) oraz kwas pelargonowy (PL). Najczęściej stosowane połączenia herbicydów to: chlomazon + metrybuzyna (PL, DE, CZ, LT), flufenacet + metrybuzyna (PL, DE, CZ, SK) i metrybuzyna + prosulfokarb (PL, DE, CZ, SK).

Najwięcej substancji czynnych insektycydów oraz ich grup chemicznych jest dostępnych do ochrony ziemniaka w Niemczech, a najmniej na Litwie (tab. 3). Podobnie, analizując mechanizmy działania insektycydów stwierdzono, że największą ich liczbą dysponują Niemcy (10), a najmniejszą Litwa (4). Niewielki asortyment substancji na Litwie należących jedynie do czterech, a jeśli pominiemy olej 
parafinowy, to do trzech grup chemicznych znacznie ogranicza możliwości rotacji i może sprzyjać większemu ryzyku rozwoju odporności szkodników na stosowane środki. We wszystkich pięciu krajach stosuje się: acetamipryd, beta-cyflutrynę, cypermetrynę, deltametrynę, imidachlopryd, lambda-cyhalotrynę, tiachlopryd i tiametoksam. Pozostałe substancje stosuje się rzadziej, jedynie w wybranych krajach. Kilka substancji wchodzi w skład insektycydów zarejestrowanych do ochrony ziemniaka tylko w jednym kraju, a są to: esfenwalerat (DE), olej parafinowy (LT), olej rzepakowy (DE), pyretryny (DE) oraz fosmet (PL). W ochronie insektycydowej stosowane są także środki zawierające połączenia substancji czynnych, a najczęściej jest to połączenie: deltametryna + tiachlopryd (PL, CZ, SK, LT).

Na podkreślenie zasługuje niewielka dostępność środków biologicznych opartych na mikroorganizmach, olejach i różnego typu wyciągach roślinnych. Te które są zarejestrowane, dostępne są tylko w niektórych spośród analizowanych państw. Do ochrony ziemniaka przed szkodnikami dostępny jest jeden szczep bakterii Bacillus thuringiensis subsp. tenebrionis (tylko w Polsce i Niemczech), spinosad produkowany przez bakterie (PL, DE, CZ, SK), olej parafinowy (tylko na Litwie), azadirachtyna (DE, CZ, LT, SK) oraz pyretryny naturalnego pochodzenia w mieszaninie z olejem rzepakowym (tylko w Niemczech). Do walki z chorobami ziemniaka zarejestrowane są dwa gatunki grzybów: Coniothyrium minitans (jedynie w Niemczech) i Pythium oligandrum (tylko w Czechach i na Słowacji) oraz jeden szczep bakterii Pseudomonas sp. Kmen DSZM13134 (tylko w Czechach).

Nie zawsze większy areał uprawy oznacza większy asortyment dostępnych środków ochrony roślin. Koronnym przykładem są tu Czechy, które mają najwięcej środków do ochrony ziemniaka ogółem, mimo areału znacznie mniejszego niż Polska czy Niemcy. Także na Litwie, chociaż areał uprawy ziemniaka jest ponad dwukrotnie większy w stosunku do Słowacji, liczba środków ochrony roślin oraz substancji czynnych jest zdecydowanie mniejsza. We wszystkich analizowanych krajach obowiązują takie same procedury dopuszczania środków ochrony roślin do obrotu i stosowania, a co więcej istnieją ścieżki rejestracyjne, które umożliwiają rejestrację jednego preparatu w kilku krajach jednocześnie. Mimo, iż od wejścia w życie Rozporządzenia $1107 / 2009$ do dnia przeprowadzenia analizy minęło prawie sześć lat, to dostępność preparatów w poszczególnych krajach jest wciąż silnie zróżnicowana (Matyjaszczyk i Sobczak 2017b).

\section{Wnioski / Conclusions}

Analiza środków zarejestrowanych do ochrony ziemniaka w Polsce i państwach sąsiednich pozwala stwierdzić, że:

1. Dostępność środków ochrony roślin oraz substancji czynnych jest zróżnicowana w analizowanych krajach. Widoczne są także znaczne różnice w rodzaju dostępnych substancji oraz liczbie ich grup chemicznych i mechanizmów działania. W każdej grupie (fungicydy, herbicydy oraz insektycydy) jest przynajmniej kilka substancji zarejestrowanych tylko w jednym spośród pięciu analizowanych państw.

2. Najwięcej preparatów do ochrony ziemniaka zarejestrowanych jest w Czechach, gdzie areał uprawy ziemniaka jest ponad 10-krotnie mniejszy w porównaniu z Polską czy Niemcami.

3. Wśród analizowanych państw w Czechach dostępnych jest najwięcej herbicydów oraz insektycydów, a w Polsce jest najwięcej fungicydów. Najmniejszą liczbę preparatów, bez względu na grupę środków, odnotowano na Litwie, która ma powierzchnię uprawy ziemniaka niewiele mniejszą niż Czechy i znacznie większą niż Słowacja.

4. Liczbowa dostępność środków ochrony roślin nie zawsze pokrywa się z ich większą różnorodnością. $\mathrm{Na}$ przykład wśród analizowanych państw członkowskich najwięcej insektycydów zarejestrowanych jest w Czechach, jednak różnorodność środków największa jest w Niemczech ze względu na większą liczbę grup chemicznych substancji czynnych oraz ich mechanizmów działania.

5. W niektórych analizowanych państwach, w tym zwłaszcza na Litwie, mogą wystąpić problemy z rotacją środków w ochronie przed konkretnymi organizmami szkodliwymi. Widać to już na podstawie ogólnej analizy dostępności, przedstawionej w niniejszej publikacji. W praktyce liczba preparatów dostępnych dla poszczególnych zastosowań (np. ochrona ziemniaka przed stonką ziemniaczaną czy rizoktoniozą) jest prawie zawsze mniejsza (a często znacznie mniejsza) niż ogólna liczba środków z danej grupy na rynku. Niewielkie możliwości rotacji są szczególnie zauważalne w ochronie przed szkodnikami.

6. Dostępność środków mikrobiologicznych oraz opartych na substancjach pochodzenia naturalnego jest słaba. Preparatów jest niewiele i są one dostępne tylko w niekórych państwach.

\section{Literatura / References}

Adamczewski K., Kierzek R., Matysiak K. 2014. Biotypes of scentless chamomile Matricaria maritima (L.) ssp. inodora (L.) Dostal and common poppy Papaver rhoeas (L.) resistant to tribenuron methyl, in Poland. Journal of Plant Protection Research 54 (4): $401-406$. DOI: $10.2478 /$ jppr-2014-0060.

BVL - Bundesamt für Verbraucherschutz und Lebensmittelsicherheit, Verzeichsnis Zugelassener Pflanzenschutzmittel - Standardsuche. 2017. https://apps2.bvl.bund.de/psm/jsp/index.jsp?modul=form [Accessed: 03.01.2017]. 
EPPO - European and Mediterranean Plant Protection Organization 2015. PP 1/213 (4) Resistance risk analysis. Bulletin OEPP/EPPO Bulletin 45 (3): 371-387. DOI: 10.1111/epp.12246.

Eurostat 2017. Crop Statistics. http://ec.europa.eu/eurostat/data/database [Accessed: 31.01.2017].

Kapsa J. 2002. Zmiany w europejskich populacjach Phytophthora infestans. Biuletyn Instytutu Hodowli i Aklimatyzacji Roślin 223/224: $329-335$

Lemańczyk G., Lisiecki K. 2015. Występowanie patogenów i chorób roślin w warunkach nawadniania. [Occurrence of pathogens and plants diseases in irrigation conditions]. Infrastruktura i Ekologia Terenów Wiejskich. Infrastructure And Ecology Of Rural Areas Nr III/1/2015, Polska Akademia Nauk, Oddział w Krakowie: 647-662. DOI: http://dx.medra.org/10.14597/infraeco.2015.3.1.052.

Matyjaszczyk E., Sobczak J. 2017a. Nowe substancje aktywne herbicydów stosowane w Polsce. Przemysł Chemiczny 96 (1): $245-247$. DOI: $10.15199 / 62.2017 .1 .31$

Matyjaszczyk E., Sobczak J. 2017b. Common EU registration rules and their effects on the availability of diverse plant protection products: A case study from oilseed rape and potato in 5 Member States. Crop Protection 96: 258-264. DOI: 10.1016/j.cropro.2017.06.006.

Matyjaszczyk E., Sobczak J., Szulc M. 2015. The legal changes regarding chemical protection used by amateurs, available active substances and the expected impact on the development of pest resistance in Poland. Journal of Central European Agriculture 16 (2): 140-148. DOI: 10.5513/JCEA01/16.2.1601.

MRiRW - Ministerstwo Rolnictwa i Rozwoju Wsi 2017. Wyszukiwarka środków ochrony roślin https://bip.minrol.gov.pl/InformacjeBranzowe/Produkcja-Roslinna/Ochrona-Roslin/Wyszukiwarka-srodkow-ochrony-roslin [dostęp: 03.01.2017].

Mrówczyński M. (red.). 2013. Integrowana ochrona upraw rolniczych. Podstawy integrowanej ochrony. T. 1. PWRiL, Poznań, 153 ss. ISBN 978-83-09-01152-1.

Nowaczyk K., Obrępalska-Stęplowska A. 2006. Wybrane mechanizmy nabywania odporności organizmów na środki ochrony roślin. [Chosen mechanisms of acquiring organisms resistance towards pesticides]. Postępy Biologii Komórki 33 (1): 137-158.

ÚKZÚZ - Ústřední kontrolní a z kušební ústav zemědělský. Registr přípravků na ochranu rostlin. 2017. http://eagri.cz/public/app/ eagriapp/POR/Vyhledavani.aspx?type=0\&vyhledat=A\&stamp=1438154442628 [Accessed: 03.01.2017].

ÚKSƯP - Ústredný kontrolný a skúšobný ústav pol’nohospodársky v Bratislave, Prípravky na ochranu rastlín. 2017. Zoznam autorizovaných prípravkov. http://www.uksup.sk/orp-pripravky-na-ochranu-rastlin-registre-a-zoznamy/ [Accessed 03.01.2017].

The Pesticide Manual 2012. Sixteen Edition (C. MacBean, eds.). BCPB, 1440 pp.

The State Plant Service under the Ministry of Agriculture 2017. Plant Protection Products Authorisation Division. http://www.vatzum.lt/ 1t/veikla/veiklos-sritys/augalu-apsaugos-produktu-registravimas/\#raap [Accessed: 03.01.2017].

Węgorek P. 2007. Historia odporności owadów na insektycydy na przykładzie stonki ziemniaczanej (Leptinotarsa decemlineata Say). Instytut Ochrony Roślin, Poznań, 68 ss. ISBN 978-83-89867-80-3. 